\title{
Patriotyzm ekonomiczny - droga do wzmocnienia gospodarki czy droga donikąd?
}

\section{Wstęp}

Patriotyzm gospodarczy, deklarowany i odmieniany na wszelkie sposoby, robi ostatnio furorę w prorządowych, czyli „narodowych”, a niegdyś publicznych, mediach, w dyskusjach publicystów oraz w wypowiedziach funkcjonariuszy polskiego rządu. Warto więc, a nawet trzeba, postawić pytanie o to, czy i jak być gospodarczym patriotą? Czy patriotą gospodarczym jest ktoś, kto za samo zło uznaje wszystko to, co jest inne, obce, bo pochodzi spoza naszych granic i nie jest generowane przez polskich pracowników, menedżerów i właścicieli (przedsiębiorców)?

Patriotyzm ekonomiczny to podejmowanie świadomych decyzji ekonomicznych z uwzględnieniem pozytywnego wpływu tych wyborów na wspólnotę narodową (państwową), z którą dany podmiot się identyfikuje ${ }^{1}$. Jako decyzje ekonomiczne należałoby rozumieć nie tylko zakupy towarów (dóbr konsumpcyjnych) czy korzystanie ze świadczonych przez rodzime podmioty usług, ale również wybieranie krajowych dostawców i kooperantów. Patriotyzm ten nie dotyczy zatem wyłącznie konsumentów, ale także podmiotów gospodarczych, jak i urzędów publicznych.

Dyskusja o patriotyzmie gospodarczym zaczęła się w Polsce już przed wielu laty, a zaktywizowała w okresie ostatnich kilku lat, zwłaszcza w czasie globalnego kryzysu finansowego. Nie jest więc-jak o tym zapewniają rządowi funkcjonariusze w reżimowych

${ }^{1}$ T. Dziewulski, Patriotyzm ekonomiczny - czy to ma sens?, https://wspieramrozwoj.pl/artykul/82/patriotyzm-ekonomiczny-czy-ma-sens [dostęp: 19.02.2020]. 
mediach - autonomicznym dziełem „dobrej zmiany”2. Patriotyzm gospodarczy nie jest też absolutnie koncepcją nową, a jego światowa historia sięga co najmniej początków rewolucji przemysłowej, zatem XVIII wieku, jeśli nie okresu jeszcze wcześniejszego. W Polsce koncepcja ta zyskała na popularności po odzyskaniu niepodległości w 1918 roku, przejawiając się choćby w wyraźnym wsparciu rozbudowy polskiej gospodarki, głównie przemysłu, a także wielkich inwestycji infrastrukturalnych, będących przedmiotem narodowej dumy ${ }^{3}$.

Z nastaniem ,dobrej zmiany” hasło patriotyzmu gospodarczego stało się jednak jednym z najczęściej głoszonych. Powstać miał zatem plan rozwoju Polski na najbliższe ćwierćwiecze, według którego nasza gospodarka miała być silna przede wszystkim kapitałem krajowym ${ }^{4}$. Otoczenie polskiego biznesu miało zaś stać się lepsze, a warunki działania „przewidywalne i transparentne”. Polskim przedsiębiorcom miałby w trudnych warunkach krajowej i międzynarodowej konkurencji pomagać specjalny fundusz rozwoju - powstały z połączenia kilku instytucji, m.in. KUKE, BGK, PARP ${ }^{5}$. Oczywiście gdyby nie dzisiejsza znajomość realnych działań ekipy „dobrej zmiany” i jej popleczników w gospodarce, można by przyjąć tę deklarację jako poważną zmianę na lepsze, choć zmiany te nie oznaczałyby automatycznie wdrożenia zasad gospodarczego patriotyzmu.

Współcześnie patriotyzm jako zjawisko społeczne przestał być bezwzględnie wymagany przez świat polityki; jest on wszelako jednostce nadal bardzo potrzebny, zwłaszcza dla własnego komfortu psychicznego, bo - w świecie postępującej indywidualizacji jednostka potrzebuje jakiejś wyraźnej grupy odniesienia, potrzebuje też poczucia więzi i tożsamości ${ }^{6}$. W dzisiejszym świecie ojczyzna nie wymaga od nas tradycyjnych postaw patriotycznych, pełnych heroizmu, lecz to wymagania naszej duchowej tożsamości powodują, że musimy być patriotami, jeżeli chcemy zachować swoją tożsamość.

Dziś zatem jedną z najważniejszych form patriotyzmu jako takiego staje się patriotyzm gospodarczy, który - na poziomie najbardziej ogólnym - oznacza dbałość o dobrą kondycję gospodarczą krajuํ. Cóż jednak oznacza to w gospodarczej praktyce? Na tę kwestię warto spojrzeć zarówno z punktu widzenia nabywcy dóbr i usług, jak i jego wytwórcy oraz aparatu państwowego jako regulatora rynku.

Artykuł ma na celu przede wszystkim określenie dzisiejszego znaczenia patriotyzmu ekonomicznego (bądź - zamiennie - gospodarczego) z perspektywy obu stron kontaktów rynkowych, a więc konsumenta (nabywcy) i producenta (dostawcy). Jest to o tyle istotne, iż nie można patrzeć na tę, jakże istotną, kwestię wyłącznie z perspektywy na-

2 E. Mączyńska-Ziemacka, T. Maćkowiak, Dobre, bo polskie, http://miesiecznik.wdrodze.pl/index. php?mod=archiwumtekst\&id=16198\#.XoloynLgrIV [dostęp: 19.02.2020].

3 J. Zielazna, Nasza ekonomia to drogi i bezdroża, wywiad z prof. Elżbietą Mączyńska, https://plus.pomorska.pl/nasza-ekonomia-to-drogi-i-bezdroza/ar/9957512 [dostęp: 10.03.2020].

${ }^{4}$ L. Kostrzewski, P. Miączyński, Patriotyzm gospodarczy robi furorę w mediach. Będa zmiany w prawie, http:// wyborcza.biz/biznes/1,147584,19980984,patriotyzm-gospodarczy-robi-furore-w-mediach-beda-zmiany-w.html [dostęp: 19.02.2020].

5 Tamże.

${ }^{6}$ Ł. Skoczylas, Patriotyzm konsumencki: próba spojrzenia socjologicznego, „Ruch Prawniczy, Ekonomiczny i Socjologiczny" 2013, z. 4, s. 216.

7 E. Mączyńska-Ziemacka, T. Maćkowiak, dz. cyt. 
bywcy - bo zacieśnia to perspektywę badawczą wyłącznie do zjawiska etnocentryzmu konsumenckiego. Wobec powyższego podjęto próbę pewnego określenia (bo przecież nie zdefiniowania) obu pojęć, znalezienia ich cech wspólnych, ale też wskazania istotnych różnic pomiędzy nimi.

W opracowaniu starano się również wskazać na możliwość poszukiwania (czy znalezienia? - to pozostaje wciąż kwestią dyskusyjną) pewnego balansu między skrajnymi postawami rynkowymi, tj. ekonomicznym kosmopolityzmem a nacjonalizmem gospodarczym. Wydaje się bowiem, że jakiekolwiek skrajności w postawach i zachowaniach o podłożu rynkowym są, zwłaszcza współcześnie, słabo przystające do dzisiejszej rzeczywistości gospodarczej.

\section{Perspektywa konsumenta}

Społeczeństwo konsumpcyjne, a więc takie, które się u nas kształtuje, ocenia swoich członków na podstawie ich zachowań konsumenckich ${ }^{8}$. Konsumpcja może być zjawiskiem niesprzyjającym patriotyzmowi, może być wobec niego neutralna, ale też może stanowić jego przejaw - wszystko zależy od nie tylko deklarowanych, ale i realizowanych w praktyce postaw, wyborów, działań.

Patriotyzm konsumentów w Polsce, w warunkach globalizacji, ulegał dynamicznej zmianie9. Dzięki każdej świadomej decyzji konsumenckiej możemy przyczynić się do tego, że kapitał pozostanie w kraju, a to z kolei pozwala producentom na rozwój oraz tworzenie nowych miejsc pracy ${ }^{10}$. Szczególnie więc w handlu wielu przedsiębiorców, zwłaszcza działających od wielu lat, chętnie eksponuje i podkreśla swoją polskośćc ${ }^{11}$.

Polacy rzeczywiście coraz bardziej i coraz częściej interesują się pochodzeniem nabywanych produktów: przez to chcą być świadomymi konsumentami i wybierać rodzime artykuły, choć - przy napływie zagranicznych towarów - często nie są w stanie odróżnić polskich marek od marek obcych ${ }^{12}$.

Patriotyzm gospodarczy to oczywiście także decyzje konsumenckie, wybór polskich produktów $^{13}$, promowanie ich, bo kreując modę na polskie produkty, możemy zrobić wiele dobrego dla polskiej gospodarki ${ }^{14}$. W wypadku konsumentów oznacza to, że we wszystkich swoich zachowaniach rynkowych, a zwłaszcza w trakcie dokonywania zakupów

\footnotetext{
8 Ł. Skoczylas, dz. cyt., s. 216.

9 K. Włodarczyk, Globalizacja a patriotyzm ekonomiczny polskich konsumentów, „Studia Ekonomiczne. Zeszyty Naukowe Uniwersytetu Ekonomicznego w Katowicach”2015, nr 214, s. 69 i nast.

10 Patriotyzm gospodarczy a decyzje zakupowe Polaków, https://biznes.newseria.pl/komunikaty/patriotyzm-gospodarczy-a,b2026028150 [dostęp: 19.02.2020].

11 Szerzej w: K. Kaszuba, Patriotyzm przy sklepowej półce, „Wiadomości Handlowe” 2013, nr 9(128).

12 Patriotyzm gospodarczy..., dz. cyt.

13 A. Tycner, Patriotyzm gospodarczy nie równa się walce z zagranicznym kapitałem, http://finanse.wnp. pl/patriotyzm-gospodarczy-nie-rowna-sie-walce-z-zagranicznym-kapitalem, $273028 \quad 1 \quad 0 \quad 0 . h t m l$ [dostęp: 19.02.2020].

14 J. Kowalczyk, Co oznacza „patriotyzm gospodarczy” dla Polaków, https://www.pb.pl/co-oznacza-patriotyzm-gospodarczy-dla-polakow-868098 [dostęp: 19.02.2020].
} 
towarów oraz usług powinni kierować się wyłącznie korzyściami dla swojego kraju ${ }^{15}$. Często jednakże konsumentom brakuje wiedzy, gdy nie mogą odnaleźć informacji, czy produkt jest krajowy, czy też zagraniczny.

Patriotyzm ekonomiczny nie musi też oznaczać kupowania rodzimych (krajowych) produktów za wszelką cenę, a więc również tych zbyt drogich lub niskiej jakości, tylko dlatego, że są polskie ${ }^{16}$.

„Nowy” patriotyzm konsumencki to w istocie bardziej poświęcenie dla konkretnej marki lub przedsiębiorstwa. Kupując określone produkty, możemy mieć poczucie, że wspieramy „narodowy” przemysł, ale bezpośrednio wspieramy tylko właścicieli (i - jedynie w pewnym stopniu, wcale nie zawsze - pracowników) danego przedsiębiorstwa. Przedsiębiorstwa wykorzystują zresztą ten trend patriotyczny, tworząc marki „,narodowe”, które wprost odwołują się do wartości związanych z poczuciem przynależności do narodu ${ }^{17}$.

Marka narodowa stanowi szczególny rodzaj marki, zorientowanej na zaspokojenie określonych potrzeb emocjonalnych klienta, wynikających z silnie wykształconego u niego poczucia tożsamości i dumy narodowej. Tworzenie takiej marki umożliwia przedsiębiorcom wyróżnianie ich produktu spośród wielu innych produktów globalnych; ponadto może wpłynąć na zmniejszenie kosztów marketingowych w wyniku utożsamienia z ich produktami pewnych powszechnie znanych i cenionych symboli, związanych pierwotnie $\mathrm{z}$ narodem.

Marka narodowa stanowi także odpowiedź na powstanie społeczeństwa konsumpcyjnego, w którym dóbr jest dużo, problemem pozostaje natomiast popyt na nie - aby go wytworzyć, trzeba odwoływać się do emocji klienta, a nie tylko do argumentów racjonalnych. Tworzenie marek narodowych jest więc swoistą odpowiedzią na zmiany w społeczeństwach zachodniego kręgu kulturowego, których częścią jest wytworzenie się ,nowego" patriotyzmu ${ }^{18}$.

Pewnym wyjaśnieniem wzrastającej popularności polskich produktów może być odczuwana przez rzesze ludzi nostalgia za przeszłością, również za tą związaną z czasami PRL, która nie jest wcale tak jednoznacznie źle oceniana. Producenci mogą więc korzystać bądź z tego, że pewne produkty dostępne są od wielu lat, bo sprzedawane były także w czasach PRL, bądź z tego, że dużej liczbie konsumentów kojarzą się z okresem dzieciństwa i młodości ${ }^{19}$.

Nie można jednak patriotyzmu gospodarczego sprowadzać tylko do etnocentryzmu konsumenckiego, do tego, by nabywać wyłącznie, bądź przede wszystkim, polskie produkty. Problem jest w istocie jeszcze bardziej złożony.

15 K. Włodarczyk, dz. cyt., s. 67.

16 S. Ostrowski, Patriotyzm ekonomiczny to nie jest kupowanie produktu tylko dlatego, że jest polski, https://biznesnaostro.pl/patriotyzm-ekonomiczny-to-nie-jest-kupowanie-produktu-tylko-dlatego-ze-jest-polski/ [dostęp: 19.02.2020].

17 Ł. Skoczylas, dz. cyt., s. 219.

18 Tamże, s. 220.

19 Tamże. 
Sama zasada etnocentryzmu konsumenckiego jest przy tym na pozór, ale tylko na pozór, bardzo prosta - chodzi o wybieranie tego, co polskie, zamiast tego, co zagraniczne ${ }^{20}$. Cóż jednak znaczy dziś, w dobie globalizacji i dominacji na światowych rynkach korporacji transnarodowych (KTN), pojęcie ,polskiego” produktu? Czy gospodarczym patriotą jest więc ktoś, kto nawet kupuje produkty pochodzące od polskich producentów, ale w obcych hipermarketach, czy może dokonujący zakupów w „,polskich” sklepach, ale wybierający $\mathrm{w}$ nich towary pochodzenia zagranicznego?

Czynnikiem, który zasadniczo komplikuje dokonywanie wyborów konsumenckich w Polsce (ale w czasach globalizacji również w innych krajach), jest nie zawsze klarowne rozgraniczenie tego, które marki są „,polskie”, a które „,zagraniczne”21.

Niewystarczające zrozumienie złożoności współczesnej gospodarki prowadzi zatem do paradoksalnych sytuacji. Jakże niedawno bowiem środowiska utożsamiane z ekonomicznym patriotyzmem, a przynajmniej same siebie tak określające (choć jest to określenie dalekie od prawdy), zaczęły powielać tzw. efekt 590. Również reżimowe media, opanowane przez ludzi nienawykłych do prawdomówności, zaczęły powielać fałszywą informację, jakoby to właśnie ów prefiks 590 w kodzie kreskowym pozwalał jednoznacznie zidentyfikować ,prawdziwie polski” produkt. Problem wszakże w tym, iż liczba ta określa wyłącznie miejsce rejestracji działalności gospodarczej - i nic ponadto. W wielu wypadkach oznacza to zaś spółki-córki zagranicznych koncernów, tworzące miejsca pracy w odległych krajach i transferujące zyski do swych oddziałów macierzystych ${ }^{22}$. Dzięki nasilonej propagandzie jakże doskonale przyjmują się w społecznej świadomości myślowe protezy, skutecznie uzupełniające (wypełniające) intelektualne deficyty.

W kontekście patriotyzmu konsumenckiego ważną kwestią wydaje się także swoisty konsumencki patriotyzm lokalny, czyli preferowanie produktów z danego regionu wobec szerokiej oferty dóbr nie tylko globalnej, lecz także ogólnokrajowejej

Wielu z nas, myśląc o patriotyzmie ekonomicznym, nastawia się na robienie zakupów w lokalnych sklepach, zwanych nieraz potocznie osiedlowymi czy rodzinnymi ${ }^{24}$.

Sprawa wydaje się poniekąd słuszna, bo w końcu wspieramy w ten sposób swoich bezpośrednich sąsiadów, często znajomych, a nie wielkie markety i zagraniczne sieci handlowe (byłby to wszelako patriotyzm lokalny, uznawany czasem za przeciwieństwo „prawdziwego" patriotyzmu).

Problem jest w tym, że te najmniejsze sklepiki przeważnie mają w swoim asortymencie głównie produkty będące wytworami wielkich korporacji, często wytwarzane za granicą, a pozbawione są produktów rodzimych, zwłaszcza tych lokalnych ${ }^{25}$. Czy w tej sytuacji owe lokalne sklepy same z siebie wykazują się działaniami choćby zbliżonymi do patriotyzmu ${ }^{26}$.

20 T. Dziewulski, dz. cyt.

${ }^{21}$ D. Maison, T. Baran, Dobre, bo (nie)polskie? O uwarunkowaniach i konsekwencjach etnocentryzmu konsumenckiego, „Marketing i Rynek” 2014, nr 10, s. 3.

${ }^{22}$ T. Geodecki, B. Radziejewski, Kosmopolityzm kontra szowinizm, http://biznes.gazetaprawna.pl/artykuly/1011470,patrotyzm-gospodarczy-globalizacja.html [dostęp: 19.02.2020].

23 Ł. Skoczylas, dz. cyt., s. 223.

24 T. Dziewulski, dz. cyt.

25 Tamże.

${ }^{26}$ Patriotyzm gospodarczy..., dz. cyt. 


\section{Perspektywa producenta}

Warto spojrzeć na kwestie patriotyzmu gospodarczego z punktu widzenia podmiotów gospodarczych, polskich przedsiębiorców, prowadzących w Polsce - na małą i dużą skalę - swoją działalność gospodarczą. Polskie przedsiębiorstwa również skłaniają się ku działalności promującej patriotyzm ekonomiczny i wspieranie rodzimej produkcji, choć czynią to raczej z myślą o powodzeniu własnego biznesu, a nie interesie gospodarczym państwa ${ }^{27}$. Przekonanie, że patriotyzm gospodarczy to dobry, być może jedyny sposób na budowę silniejszej gospodarki, wcale nie jest powszechnie podzielane przez przedsiębiorców ${ }^{28}$.

W patriotyzmie gospodarczym chodzi wszak o to, by dbać o kondycję narodowej gospodarki, a najlepszą tego formą jest dbałość o wysoką jakość i wydajność pracy, o innowacyjność polskich przedsiębiorstw i produktów, co sprawi, że stają się one konkurencyjne na światowych rynkach ${ }^{29}$. Wielkie wezwania do patriotyzmu, do kupowania rodzimych wyrobów nic bowiem nie pomogą, a staną się wręcz szkodliwe, jeśli nasze rodzime towary będą marnej jakości; zaufanie do produktów danego kraju najlepiej buduje ich dobra jakość.

Przyjrzyjmy się temu problemowi z szerszej perspektywy, nie tylko wytwórczej - patriotyzm gospodarczy to przecież także świadome wykorzystywanie rodzimych technologii. Patriotyzm gospodarczy powinien sprowadzać się więc choćby do produkcji w Polsce innowacyjnych towarów o wysokiej jakości, które będą chcieli kupować sami Polacy. Takie produkty będą też pożądane na rynkach zagranicznych, stanowiąc najlepszą polską wizytówkę ${ }^{30}$.

Patriotyzm gospodarczy powinien oznaczać też m.in. (a może przede wszystkim) budowę silnych polskich firm i marek, godnych tego, by uznać, że „made in Poland” może oznaczać coś, z czego można i warto być dumnym ${ }^{31}$.

Przedsiębiorcy - jakże często - za gospodarczy patriotyzm uznają wspieranie ich rozwoju (na rynku krajowym i międzynarodowym) przez krajowe ustawodawstwo i aktywne działania $\mathrm{rządu}^{32}$. Z drugiej strony spora ich część podchodzi z wielkim dystansem do jakichkolwiek obowiązków wobec państwa i jego obywateli, zwłaszcza swych własnych pracowników.

Specyficznie rozumiany patriotyzm gospodarczy jest utożsamiany z protekcjonizmem. Jeśli jednak chcemy, by polskie produkty zdobywały zagraniczne rynki, jeśli - jak najbardziej słusznie - aspirujemy do tego, by polskie produkty były obecne na świecie, to nie możemy budować barier dla zagranicznych produktów w kraju. Musimy zaś dążyć

\footnotetext{
27 Tamże.

${ }_{28}$ G. Siemionczyk, Patriotyzm gospodarczy czy zwykty protekcjonizm, http://www.parkiet.com/artykul/1495234.html?print=tak [dostęp: 19.02.2020].

${ }^{29}$ E. Mączyńska-Ziemacka, T. Maćkowiak, dz. cyt.

${ }^{30}$ G. Siemionczyk, dz. cyt.

31 S. Ostrowski, dz. cyt.

32 A. Tycner, dz. cyt.
} 
do tego, by likwidować bariery poza granicami naszego kraju, a nie wznosić je u nas ${ }^{33}$. Nie chodzi więc o jakieś nadzwyczajne działania, tylko o naprawę pewnych dotychczasowych zaniechań. Musimy raczej koncentrować się na rozwiązaniach pozytywnych, być za czymś, a nie przeciwko czemuś.

Patriotyzm zatem może, a nawet powinien wyrażać się etosem pracy; ten etos przekładałby się zaś na wysoką jakość krajowej produkcji, a w efekcie jej atrakcyjność i konkurencyjność na świecie ${ }^{34}$. Za przejaw gospodarczego patriotyzmu należałoby uznać także zatrudnianie pracowników na godnych warunkach, nieuwłaczających poczuciu godności.

Warto zadać kolejne pytanie: Czego oczekują od rządu polscy przedsiębiorcy? Dobrze działający prywatny przedsiębiorca nie oczekuje (nie powinien oczekiwać) żadnej pomocy od państwa, bo budowanie biznesu na takich nadziejach czy założeniach byłoby nie tylko nieuczciwe, ale wręcz gospodarczo irracjonalne. Ważne jest co innego - stabilny, jasny i sprawiedliwy (cokolwiek to znaczy) system podatkowy i prawny.

Nowoczesny patriotyzm gospodarczy to również uczciwe płacenie podatków. Warto zatem postawić pytanie, gdzie polski przedsiębiorca - patriota, domagający się tego, by za wszelką cenę nabywać właśnie jego produkty i chronić jego działalność przed zagraniczną konkurencją, powinien je płacić. W Polsce czy może w innym kraju, w którym są mniejsze obciążenia podatkowe? To drugie wyjście wydaje się racjonalne z punktu widzenia biznesowego, tzw. optymalizacji podatkowej.

Jedną z najważniejszych powinności obywatela, zwłaszcza mieniącego się patriotą, tak producenta, jak i konsumenta, jest płacenie podatków i bezwzględne podporządkowanie się regułom, które obowiązują $\mathrm{w} \mathrm{kraju}^{35}$. Z całą pewnością zatem nie możemy nazwać patriotą kogoś, kto wprawdzie deklaruje, że kocha swoją ojczyznę, ale podatki woli płacić za granicą, na przykład w rajach podatkowych.

\section{Perspektywa państwa}

Choć pewne grupy polityczne i biznesowe próbują budować swoją pozycję polityczną i ekonomiczną na panicznym wręcz strachu przed kapitałem zagranicznym, zagranicznymi inwestycjami, to przecież jeśli zagraniczny inwestor jest poważny, daje gwarancję rozwoju przedsiębiorstwa i wykazuje skłonność, by podporządkować się naszym krajowym regułom gry, to jego działania wypadałoby uznać za korzystne.

Polska jest niestety krajem wciąż ubogim w kapitał, więc gdybyśmy mieli rozwijać się wyłącznie w oparciu o kapitał rodzimy, to byśmy się w ogóle nie rozwijali - my po prostu nie mamy dość kapitału i musimy go importować. Jednym z najważniejszych działań powinno być zatem powstrzymanie odpływu kapitałów za granicę przy założeniu, że w gospodarce kapitalistycznej to właśnie kapitał stanowi kluczowy czynnik rozwoju ${ }^{36}$.

33 G. Siemionczyk, dz. cyt.

34 Tamże.

35 A.K. Koźmiński, Między ekonomia a patriotyzmem, http://www.instytutobywatelski.pl/11278/lupa-instytutu/miedzy-ekonomia-a-patriotyzmem [dostęp: 19.02.2020].

36 T. Dziewulski, dz. cyt. 
Formą patriotyzmu gospodarczego będzie także zachęcanie zagranicznych przedsiębiorców do inwestowania w Polsce, do zatrudniania polskich pracowników, ale na godnych warunkach płacowych, a przy tym płacących podatki w Polsce ${ }^{37}$.

Patriotyzm gospodarczy to natomiast z całą pewnością wspieranie inwestycji i ekspansji polskich przedsiębiorstw w kraju i za granicą, tworzenie dobrego klimatu do inwestycji, rozwoju i konkurencji, wreszcie odbudowa polskiego przemysłu. Mądre wsparcie administracji publicznej dla biznesu może znakomicie przyspieszyć rozwój polskich przedsiębiorstw na rynkach międzynarodowych ${ }^{38}$. Wymaga to jednak zmiany postrzegania państwa i jego roli w gospodarce. Propagowane przez wiele lat hasło „kapitał nie ma ojczyzny" sprzyjało wyzbywaniu się - nieraz za bezcen - polskiego majątku narodowego $^{39}$, wypracowanego jeszcze w okresie PRL. Państwo miało pełnić jedynie rolę nocnego stróża, a pomysł ten traktowano całkiem serio.

Następstwem całkowicie błędnego przekonania, iż najlepszą polityką gospodarczą jest brak jakiejkolwiek polityki oraz redukowanie funkcji państwa do jak najszybszego zbudowania wolnorynkowej gospodarki i dostarczania - także w bardzo mocno ograniczonym stopniu - klasycznych dóbr publicznych, stały się recesja gospodarcza i destrukcja rynku pracy ${ }^{40}$.

Obecnie w naszym kraju są już oczywiście przedsiębiorstwa wytwarzające dobra nowoczesne o wysokiej jakości. Jednakże nadal żyjemy w błędnym przekonaniu, że „polskie” musi oznaczać ,gorsze”, i dlatego wiele produktów kupujemy za granicą - co w Polsce wcale nie dziwi.

Wciąż przecież państwo aktywne gospodarczo zachowuje swoją rolę w świecie, także w Europie. Jest tak do dzisiaj - i to również w tych krajach, gdzie głosi się (przeważnie na użytek zewnętrzny) teorie negujące rolę państwa, przede wszystkim w Stanach Zjednoczonych ${ }^{41}$ będących - wyłącznie deklaratywnie - ostoją leseferyzmu. Najlepiej jest to widoczne w Europie na przykładzie Niemiec, a w Azji - w Japonii. Oba te kraje poniosły w ostatniej wojnie światowej ogromną klęskę militarną, wygrały natomiast w okresie pokoju, kierując się głęboko i właściwie pojętym interesem państwowym czy narodowym. W krajach tych przez długie lata państwo bardzo aktywnie angażowało się w proces budowy silnej gospodarki narodowej ${ }^{42}$.

Współczesnymi liderami nowoczesnego patriotyzmu gospodarczego, rozgrywanego właśnie w płaszczyźnie ekonomicznej są jednak także Francja, Turcja, Indie, Chiny, Korea Południowa, Rosja oraz deklarująca liberalizm gospodarczy Wielka Brytania ${ }^{43}$.

37 T. Siemieniec, dz. cyt.

${ }_{38}$ K. Rybiński, Patriotyzm ekonomiczny, http://www.rp.pl/artykul/1017626-Patriotyzm-ekonomiczny. html [dostęp: 19.02.2020].

${ }_{39}$ M. Dębowska, J. Koziar, Patriotyzm gospodarczy, http://www.niedziela.pl/artykul/74126/nd/Patriotyzm-gospodarczy [dostęp: 19.02.2020].

${ }^{40}$ G. Siemionczyk, dz. cyt.

41 M. Dębowska, J. Koziar, dz. cyt.

42 S. Stodolak, ,Kupuj polskie”. Dlaczego patriotyzm gospodarczy jest pozbawiony sensu, https://biznes. gazetaprawna.pl/artykuly/1092244,patriotyzm-gospodarczy-w-polsce.html [dostęp: 19.02.2020].

43 L. Kostrzewski, P. Miączyński, Patriotyzm gospodarczy robi furore..., dz. cyt. 
Polska to jednak specyficzny kraj, który za drogę wzrostu gospodarczego w okresie tzw. transformacji systemowej wybrał pełne otwarcie się na kapitał międzynarodowy, choć najlepiej znane przykłady sukcesu gospodarczego w Europie, Azji i Ameryce opierają się raczej na drodze wiodącej w przeciwnym kierunku${ }^{44}$.

Na poziomie gospodarki narodowej pojawiają się coraz liczniejsze głosy wzywające do nasilenia protekcjonizmu, a nawet do podejmowania wrogich działań wobec innych państw i ich gospodarek - ma to być obrona produkcji krajowej przed zagraniczną konkurencją.

W warunkach globalizacji i liberalizacji rynków patriotyzm ekonomiczny nie może być uprawiany za pomocą standardowych taryfowych, parataryfowych i pozataryfowych narzędzi polityki handlowej, gdyż te są dekretowane przez porządek prawny UE i WTO oraz międzynarodowe konwencje, których sygnatariuszem jest Polska ${ }^{45}$. Dopuszczalny prawnie jest natomiast taki patriotyzm ekonomiczny, który wypiera z rodzimych rynków nieuczciwą konkurencję, nieuczciwe transfery zysków do rajów podatkowych i położonych poza granicami spółek-matek czy realizowany w ramach polityki prywatyzacyjnej.

Można go też uprawiać poprzez zamówienia publiczne - bez nich bowiem wiele fabryk nie powstałoby, a w czasach złej koniunktury nie mogłoby przetrwać ${ }^{46}$. Być może również w przetargach powinno się preferować podmioty krajowe, najlepiej lokalne ${ }^{47}$, ale polskie prawo stanowi, iż instytucje państwowe i samorządowe w procedurach przetargowych muszą kierować się przede wszystkim kryterium najniższej ceny.

Patriotyzmem gospodarczym jest więc bez wątpienia aktywne działanie państwa. Nie jest nim natomiast zawłaszczanie państwowych przedsiębiorstw, obsadzanie coraz liczniejszych, sztucznie tworzonych stanowisk przez reżimowych funkcjonariuszy bez odpowiednich kwalifikacji ani doświadczenia zawodowego, a zainteresowanych jedynie tym, by „drenować” bez żadnego umiaru ich finanse - w interesie własnym i swych mocodawców, ale nie w interesie państwa.

Interesy polityczne, zwłaszcza dzisiejszej biurokracji państwowej, choć wskazywane jako przejawy patriotyzmu, bardzo łatwo autonomizują się. Niestety, ich działania nie znajdują odzwierciedlenia w poprawie jakości życia ludności i zwiększaniu innowacyjności gospodarki jako podstawy długookresowej konkurencyjności - na rynku wewnętrznym i międzynarodowym.

Mamy przecież liczne organizacje międzynarodowe i ponadnarodowe, propagujące i promujące szeroko pojętą współpracę gospodarczą, mamy naszą wspólną Unię Europejską, która bez wielostronnej współpracy już dawno by się rozpadła, a zapewne w ogóle by nie powstała. Współpraca ekonomiczna z innymi państwami, nawet daleko posunięta, nie wyklucza jednak wsparcia, pomocy własnym przedsiębiorstwom zarówno w kraju, jak i przy podbijaniu zagranicznych rynków ${ }^{48}$. Pomoc ta może oczywiście przyjmować różne formy. Całkowitym zaprzeczeniem patriotyzmu jest zapewne polityczny i ekonomiczny

\footnotetext{
${ }^{44}$ Czym jest patriotyzm gospodarczy?, dz. cyt.

45 G. Siemionczyk, dz. cyt.

46 Tamże.

47 T. Dziewulski, dz. cyt.

48 L. Kostrzewski, P. Miączyński, Patriotyzm gospodarczy robi furore..., dz. cyt.
} 
serwilizm wobec naszego „największego”, a często ,jedynego” sojusznika i zawieranie transakcji gospodarczych bez należnej dbałości o nasz państwowy interes.

Gospodarki krajów unijnych, także tzw. starej piętnastki, a więc silniej zintegrowane politycznie i gospodarczo od „,nowych” państw członkowskich, od lat z wielkim powodzeniem opierają swój rozwój - co najmniej po części - na gospodarczym patriotyzmie, widocznym nie tylko wśród „zwykłych” konsumentów, ale i w sferze przedsięwzięć rządowych.

Nowoczesny patriotyzm ekonomiczny nie może być zatem zamykaniem się na współpracę z innymi krajami, nie może być zamykaniem granic przed obcą konkurencją, ale uczciwym i świadomym promowaniem polskich firm i marek produktów ${ }^{49}$.

W Polsce bez wątpienia musimy także przełamać wytworzoną w okresie transformacji systemowej barierę mentalną, gdy jakikolwiek styk polityki z biznesem już niejako z założenia źle się kojarzy ${ }^{50}$. Styk ten musi być jednak wolny od jakichkolwiek działań, noszących znamiona korupcji czy choćby korupcji politycznej.

Trudno bowiem o aktywną, prorozwojową politykę państwa, gdy istnieje w naszym kraju negatywny kapitał społeczny, uzdalniający do kooperacji jedynie na rzecz partykularnych celów grup poszukujących nienależnych korzyści. Przejawem negatywnego kapitału społecznego jest zwłaszcza upartyjnienie polityki, struktur administracji państwowej i samorządowej, a także gospodarki - analogicznie jak rozwój struktur mafijnych, źle rozumianej solidarności grup zawodowych, obyczajowych, światopoglądowych, etnicznych czy innych, zorientowanych niemal wyłącznie na swoje partykularne interesy ${ }^{51}$.

\section{Podsumowanie}

Dzisiejszy patriota gospodarczy, ów realny bądź tylko potencjalny ma prawo czuć się skonfundowany ${ }^{52}$, a wręcz zdezorientowany, przez różne, czasem absurdalne, odnoszenie się w życiu publicznym do jakichkolwiek założeń i celów patriotyzmu ekonomicznego. Promowanie dziś bowiem czy wręcz premiowanie polskich podmiotów tylko ze względu na narodowość ich właścicieli, acz z pominięciem rozlicznych, towarzyszących temu okoliczności, takich jak miejsce prowadzenia działalności i miejsce płacenia podatków, jak również ceny i jakość oferowanych produktów czy usług, wydaje się nie tylko dalece nieracjonalne, ale i nieuczciwe.

Oczywiście z punktu widzenia ekonomicznego patriotyzmu alternatywa w postaci kosmopolityzmu ekonomicznego, głoszącego, iż kapitał nie ma narodowości, brzmi co najmniej równie absurdalnie.

Niestety dziś to właśnie pomiędzy tymi, jakże odległymi od siebie biegunami postaw konsumentów i producentów oscyluje polska debata publiczna, szukająca - z braku intelektualnej podbudowy - najprostszych (i jednocześnie najgłupszych) rozwiązań. Zderza-

\footnotetext{
49 S. Ostrowski, dz. cyt.

50 T. Siemieniec, dz. cyt.

51 G. Siemionczyk, dz. cyt.

${ }^{52}$ T. Geodecki, B. Radziejewski, dz. cyt.
} 
jąc się z tak złożonymi realiami, zwolennicy obu skrajnych stanowisk tylko pogłębiają pojęciowe zamieszanie.

Z jednej strony mamy zatem zaprzysięgłych kosmopolitów, z maniakalnym wręcz uporem odmawiających kryterium narodowemu jakiegokolwiek znaczenia ekonomicznego. Prezentując taką postawę, zachowują się tak, jakby nigdy w dziejach urynkowienia polskiej gospodarki nie wydarzył się upadek polskich przedsiębiorstw, zwłaszcza ten $\mathrm{u}$ zarania transformacji systemowej, czy niedawny przecież i wciąż jeszcze pamiętany światowy kryzys finansowy i gospodarczy, ale też lawinowy wręcz wzrost przepływów finansowych z krajów gospodarczych peryferii, takich jak choćby Polska, do światowych centrów finansowych i gospodarczych.

Z drugiej strony coraz bardziej widoczni w publicznej debacie są ludzie przyznający się do patriotyzmu gospodarczego (deklarujący go), choć czasem poprzestający jedynie na pustych deklaracjach. W swoim, często naprawdę szlachetnym, chociaż z punktu widzenia współczesnej gospodarki naiwnym nastawieniu, nie mają oni odpowiedzi, ani choćby podpowiedzi, na podstawowe pytania o kwestie kluczowe: rezydencję podatkową, miejsce produkcji.

W ocenie gospodarki, jej efektywności i potencjału, należałoby brać pod uwagę wskaźniki szersze aniżeli tylko wartość dochodu czy produktu narodowego i jego dynamika - choć od tych mierników, co oczywiste, uciec nie można. Patriotyzm ekonomiczny powinien natomiast oznaczać dążenie do tego, aby gdy kraj rozwija się gospodarczo, całe społeczeństwo się bogaciło. Wyrazem ekonomicznego patriotyzmu było zatem na pewno, choć często dziś wyśmiewane, hasło wywodzące się jeszcze z lat 70. XX wieku: „Aby Polska rosła w siłę, a ludzie żyli dostatniej”, przy czym obecnie jego realizacja musi się dokonywać w warunkach pewnej równowagi, akceptowanych form społecznych i politycznych ${ }^{53}$. Patriotyzm ekonomiczny powinien bowiem zakładać, iż wszystkie grupy społeczne, chociaż zapewne w niejednakowym stopniu, uczestniczą w bogaceniu się, wobec czego nie tworzą się nadmierne, nieakceptowalne społecznie różnice dochodo$w^{54}$. Takie różnice są oczywiście niezbędne i normalne, ale sytuacje skrajne są nie tylko niewskazane, ale wręcz szkodliwe.

Podobnie rzecz się ma z życiem duchowym i intelektualnym społeczeństwa, które musi być odpowiednio wspierane, wspomagane przez potencjał ekonomiczny kraju i jego obywateli, ale nie może ono ograniczać się do zwykłej indoktrynacji. Dopełnieniem szeroko rozumianego, ,wielkiego” patriotyzmu gospodarczego, także w dobie globalizacji, jest właściwie pojmowany patriotyzm lokalny. Należy bowiem dbać także o swoją „małą ojczyznę", nawet w warunkach daleko posuniętej integracji europejskiej. Nie wolno jednakże przekroczyć granicy pomiędzy patriotyzmem gospodarczym a nacjonalizmem gospodarczym, który na dłuższą metę wcale nie przyczyni się do poprawy konkurencyjności polskiej gospodarki ${ }^{55}$.

\footnotetext{
53 A.K. Koźmiński, dz. cyt.

54 Tamże.

${ }_{55}$ G. Kołodko, Prof. Kołodko: Nacjonalizm gospodarczy nie przyczyni się do konkurencyjności polskiej gospodarki, https://biznes.gazetaprawna.pl/artykuly/1090859,prof-kolodko-nie-nalezy-popadac-w-nacjonalizmgospodarczy.html [dostęp: 19.02.2020].
} 


\section{Bibliografia}

Dębowska M., Koziar J., Patriotyzm gospodarczy, http://www.niedziela.pl/artykul/74126/nd/ Patriotyzm-gospodarczy [dostęp: 19.02.2020].

Dziewulski T., Patriotyzm ekonomiczny - czy to ma sens?, https://wspieramrozwoj.pl/artykul/82/patriotyzm-ekonomiczny-czy-ma-sens [dostęp: 19.02.2020].

Geodecki T., Radziejewski B., Kosmopolityzm kontra szowinizm, http://biznes.gazetaprawna. pl/artykuly/1011470,patrotyzm-gospodarczy-globalizacja.html [dostęp: 19.02.2020].

Kaszuba K., Patriotyzm przy sklepowej półce, „Wiadomości Handlowe” 2013, nr 9(128).

Kołodko G., Prof. Kołodko: Nacjonalizm gospodarczy nie przyczyni się do konkurencyjności polskiej gospodarki, https://biznes.gazetaprawna.pl/artykuly/1090859,prof-kolodko-nienalezy-popadac-w-nacjonalizm-gospodarczy.html [dostęp: 19.02.2020].

Kostrzewski L., Miączyński P., Patriotyzm gospodarczy: Czy powinniśmy kupować tylko to, co polskie?, http://wyborcza.pl/1,155287,13261428,Patriotyzm gospodarczy_Czy powinnismy kupowac tylko.html [dostęp: 19.02.2020].

Kostrzewski L., Miączyński P., Patriotyzm gospodarczy robi furorę w mediach. Będa zmiany w prawie, http://wyborcza.biz/biznes/1,147584,19980984,patriotyzm-gospodarczy-robi-furore-w-mediach-beda-zmiany-w.html [dostęp: 19.02.2020].

Kowalczyk J., Co oznacza „patriotyzm gospodarczy” dla Polaków, https://www.pb.pl/co-oznacza-patriotyzm-gospodarczy-dla-polakow-868098 [dostęp: 19.02.2020].

Koźmiński A.K., Między ekonomiq a patriotyzmem, http://www.instytutobywatelski.pl/11278/ lupa-instytutu/miedzy-ekonomia-a-patriotyzmem [dostęp: 19.02.2020].

Maison D., Baran T., Dobre, bo (nie)polskie? O uwarunkowaniach i konsekwencjach etnocentryzmu konsumenckiego, „Marketing i Rynek” 2014, nr 10.

Mączyńska-Ziemacka E., Maćkowiak T., Dobre, bo polskie, http://miesiecznik.wdrodze.pl/ index.php?mod=archiwumtekst\&id=16198\#.XoloynLgrIV [dostęp: 19.02.2020].

Ostrowski S., Patriotyzm ekonomiczny to nie jest kupowanie produktu tylko dlatego, że jest polski, https://biznesnaostro.pl/patriotyzm-ekonomiczny-to-nie-jest-kupowanie-produktutylko-dlatego-ze-jest-polski/ [dostęp: 19.02.2020].

Patriotyzm gospodarczy a decyzje zakupowe Polaków, https://biznes.newseria.pl/komunikaty/ patriotyzm-gospodarczy-a,b2026028150 [dostęp: 19.02.2020].

Rybiński K., Patriotyzm ekonomiczny, http://www.rp.pl/artykul/1017626-Patriotyzm-ekonomiczny.html [dostęp: 19.02.2020].

Siemieniec T., Patriotyzm gospodarczy Beaty Szydto (wywiad), https://www.pb.pl/patriotyzm-gospodarczy-beaty-szydlo-wywiad-830401 [dostęp: 19.02.2020].

Siemionczyk G., Patriotyzm gospodarczy czy zwykty protekcjonizm, http://www.parkiet.com/ artykul/1495234.html?print=tak [dostęp: 19.02.2020].

Skoczylas Ł., Patriotyzm konsumencki: próba spojrzenia socjologicznego, „Ruch Prawniczy, Ekonomiczny i Socjologiczny" 2013, z. 4.

Stodolak S., „Kupuj polskie”. Dlaczego patriotyzm gospodarczy jest pozbawiony sensu, https://biznes.gazetaprawna.pl/artykuly/1092244,patriotyzm-gospodarczy-w-polsce.html [dostęp: 19.02.2020]. 
Tycner A., Patriotyzm gospodarczy nie równa się walce z zagranicznym kapitałem, http://finanse.wnp.pl/patriotyzm-gospodarczy-nie-rowna-sie-walce-z-zagranicznymkapitalem, 273028 1 0 0.html [dostęp: 19.02.2020].

Włodarczyk K., Globalizacja a patriotyzm ekonomiczny polskich konsumentów, „Studia Ekonomiczne. Zeszyty Naukowe Uniwersytetu Ekonomicznego w Katowicach”2015, nr 214.

Zielazna J., Nasza ekonomia to drogi i bezdroża, wywiad z prof. Elżbietą Mączyńską, https:// plus.pomorska.pl/nasza-ekonomia-to-drogi-i-bezdroza/ar/9957512 [dostęp: 10.03.2020].

\section{Streszczenie \\ Patriotyzm ekonomiczny - droga do wzmocnienia gospodarki czy droga donikąd?}

W polskim społeczeństwie, po okresie fascynacji zagranicą, odradzają się postawy patriotyczne. Patriotyzm ten przybiera różne formy, a jedną z nich staje się patriotyzm gospodarczy. Często sprowadza się go wyłącznie do etnocentryzmu konsumenckiego, ale musi on zyskać szerszy wymiar. Powinien dotyczyć postaw reprezentowanych nie tylko przez konsumentów, ale również przez przedsiębiorców. Nie może jednak przybierać postaci ekonomicznego szowinizmu.

Słowa kluczowe: nacjonalizm, szowinizm, patriotyzm, patriotyzm ekonomiczny

\section{Summary \\ Economic patriotism - the road to strengthen the economy or the road nowhere?}

In Polish society, after a period of fascination with 'abroad', patriotic attitudes are being revived. This 'patriotism' takes different forms, including the form of economic patriotism. It is often reduced to consumer ethnocentrism, but it also has a wider dimension. It should concern the attitudes of consumers and entrepreneurs. It cannot, however, take the form of economic chauvinism.

Keywords: nationalism, chauvinism, patriotism, economic patriotism 